Mariola Tracz

Polskie Towarzystwo Geograficzne, Oddział w Krakowie, Polska • Polish Geographical Society,

Branch in Krakow, Poland

\title{
Tendencje w rozwoju usług edukacyinych w Polsce na przykładzie szkolnictwa ponadgimnazjalnego
}

\section{Tendencies in development of education services in Poland - a case study of upper secondary education}

Streszczenie: Edukacja jest jednym z czynników wpływających na rozwój społeczno-gospodarczy społeczeństw. W procesie podnoszenia jakości zasobów intelektualnych istotny jest nie tylko poziom wykształcenia społeczeństwa, ale także ukończony profil kształcenia, który determinuje możliwości bardziej efektywnego funkcjonowania w życiu zawodowym. W opracowaniu przedstawiono wyniki analizy stanu i zmian dokonanych w szkolnictwie ponadgimnazjalnym w Polsce po 1989 roku. Szczegółowe rozważania obejmują zmiany strukturalne systemu oświatowego oraz ich wpływ na wybór przez młodzież typu szkoły. Istotną kwestią są także zmiany kierunków kształcenia ponadgimnazjalnego będące rezultatem z jednej strony wzrastających aspiracji edukacyjnych młodzieży, a z drugiej - zachodzących zmian w światowej i polskiej gospodarce oraz na rynku pracy.

\begin{abstract}
Education is one of the important factors which determine the human and economic growth. The quality of intellectual resources depends on the quality of functioning on secondary and higher education. In the process of improving the quality of intercultural resources not only the level of education of the society is essential, but also the direction of graduation, which affects social and job opportunities. The aim of the article is to determine the changes in the functioning of upper secondary education in Poland and changes of the structure of secondary education in years 1989-2012, with particular emphasis on the recent years.
\end{abstract}

Słowa kluczowe: edukacja; kierunki kształcenia; szkoły ponadgimnzajalne; usługi

Keywords: education; profile of education; service; upper secondary school

Otrzymano: 8 lutego 2014

Received: 8 February 2014

Zaakceptowano: 16 lipca 2015

Accepted: 16 July 2015

Sugerowana cytacja / Suggested citation:

Tracz, M. (2015). Tendencje w rozwoju usług edukacyjnych w Polsce na przykładzie szkolnictwa ponadgimnazjalnego. Prace Komisji Geografii Przemystu Polskiego Towarzystwa Geograficznego, 29(3), 147-160. 


\section{WSTĘP}

Obecnie w skali globalnej, regionalnej i lokalnej z różnym nasileniem uwidacznia się luka między potrzebami dynamicznie zmieniającego się rynku pracy a wykształceniem i kwalifikacjami absolwentów szkół średnich i uczelni wyższych. Szczególnie mocno zjawisko to ujawniło się w pierwszej dekadzie XXI wieku. Jest ono w znacznym stopniu powiązane z poziomem gospodarki, a także z kulturą organizacji i zarządzania. Powszechnie przyjmuje się, że jednym z istotnych czynników decydujących o kierunkach i poziomie rozwoju społeczno-ekonomicznego jest jakość funkcjonowania nauki i szkolnictwa, które wpływają na poziom wykształcenia społeczeństwa w skali lokalnej oraz regionalnej.

Powstało mnóstwo raportów, ekspertyz o stanie i funkcjonowaniu szkolnictwa, o dostosowaniu ofert kształcenia do potrzeb rynku pracy, o kompetencjach nabywanych przez uczniów i studentów oraz o dostępności i jakości usług edukacyjnych (Borowiec, 2010; Borowiec, 2011; Kluczowe dane..., 2012; Raport o stanie edukacji, 2011; Raport o stanie edukacji, 2012; Education at a Glance, 2014). Jednak na wiele postawionych pytań nadal nie ma jednoznacznych odpowiedzi. Na ile podejmowane działania modernizacyjne systemów kształcenia faktycznie determinują ich efektywne funkcjonowanie w kontekście zachodzących w skali globalnej procesów społeczno-gospodarczych oraz cywilizacyjnych? Jak w praktyce realizować pożądany model koncepcyjny powiązania gospodarki i edukacji przy tak dynamicznie zmieniającej się rzeczywistości?

Również w Polsce system szkolnictwa podlega ciągłym zmianom. Wynikają one m.in. z wejścia naszego kraju do struktur unijnych oraz wypracowanej i przyjętej przez Unię Europejską strategii współpracy w dziedzinie rozwoju edukacji. Głównymi zadaniami tej strategii i uruchomionych w tym celu programów (np. uczenie się przez całe życie) są: ograniczenie przedwczesnego kończenia edukacji przez młodzież (grupa wiekowa 16-18 lat), przebudowanie systemów szkolnictwa, modernizacja koncepcji kształcenia (reorientacja na kompetencje), zapewnienie systemom większej elastyczności oraz ściślejsze powiązanie szkolnictwa akademickiego i zawodowego z potrzebami rynku.

Przedmiotem badania jest szkolnictwo ponadgimnazjalne, w tym jego struktura i profile kształcenia. Przez określenie „szkolnictwo ponadgimnazjalne” rozumie się szkoły przeznaczone dla uczniów w grupie wiekowej 16-19 lat, a więc wyższego poziomu szkoły średniej, co odpowiada wg klasyfikacji UE poziomowi ISCED3. W niniejszym opracowaniu dokonano analizy struktury szkolnictwa ponadgimnazjalnego, w tym zróżnicowania profili kształcenia zawodowego w Polsce w latach 1990-2012. Na podstawie danych statystycznych opublikowanych przez GUS i EURYDICE dokonano również oceny rozwoju ilościowego i jakościowego szkolnictwa ponadgimnazjalnego w Polsce na tle tendencji zachodzących w wybranych krajach Unii Europejskiej w ostatniej dekadzie. W analizie opisowej posłużono się miernikami wskaźnikowymi: współczynnikiem scholaryzacji brutto i netto.

\section{EDUKACJA A USŁUGI EDUKACYJNE}

Pod pojęciem edukacji rozumie się ogół procesów dydaktycznych i wychowawczych, których celem jest wyposażenie wychowanków w wiedzę i umiejętności, a także 
ukształtowanie ich osobowości (Kupisiewicz C., Kupisiewicz M., 2009; Okoń, 2007). Edukacja może być realizowana w formie zinstytucjonalizowanej albo przybierać formy pozainstytucjonalne, w tym także okazjonalne. Głównym i pożądanym rezultatem edukacji jest osoba wszechstronnie ukształtowana pod względem intelektualnym, społeczno-moralnym, kulturalnym i zawodowym, przystosowana do życia w otaczającej ją rzeczywistości.

Przypisywanie edukacji istotnej roli w rozwoju gospodarki ma swoje uzasadnienie w zjawiskach o charakterze egzogenicznym. Można do nich zaliczyć dynamiczny rozwój techniki i technologii, powodujący wzrost znaczenia wykształcenia i posiadanych kwalifikacji. Funkcjonowanie zawodowe na współczesnym rynku pracy wymaga od człowieka stałego podnoszenia kwalifikacji, a coraz częściej także przekwalifikowania się do wykonywania nowego zawodu. W kategoriach standardu postrzega się ukończenie szkoły średniej, w tym uzyskanie matury jako podstawy dalszej edukacji zawodowej (Kluczowe dane ..., 2012; Badanie funkcjonowania ..., 2011a; Badanie funkcjonowania ..., 2011b).

Ważna rola edukacji wiąże się także ze zjawiskami o charakterze endogenicznym. Szczególnie w schyłkowych regionach przemysłowych, którym towarzyszy upadek nierentownej działalności, powinien być on rekompensowany przez rozwój innych dziedzin. Wprowadzenie tam nowych rodzajów działalności produkcyjnej i usługowej wymaga przebudowy dotychczasowej oferty edukacyjnej w szkołach oraz instytucjach oświatowych. Ponadto przełamanie recesji gospodarczej wymaga często zmiany klimatu mentalnego, niezbędnego do przeprowadzenia istotnych zmian ekonomicznych (mało popularnych, np. redukcji zatrudnienia). Zmiany mentalne uwarunkowane są edukacją społeczeństwa i lokalnych elit politycznych (Godlewska-Majkowska, 2007; Kudełko, 2007; Tkocz, 2007).

Badania nad usługami edukacyjnymi i ich rolą w rozwoju gospodarczym są stosunkowo nowym problemem badawczym. W literaturze pojęcie „usługi edukacyjne” jest różnie definiowane. Przypisuje się temu terminowi dość szerokie i ogólne znaczenie, bez podnoszenia wątku komercyjnego. Przykładem niech będzie definicja P. Kotlera (2002), według którego usługa edukacyjna jest dowodem działania, jakie jedna strona może zaoferować innej. Według E. Skrzypka (2006) usługa edukacyjna jest celowym i uporządkowanym ciągiem relacji, jakie zachodzą pomiędzy nauczającym a uczącym się.

Druga grupa definicji usług edukacyjnych bardziej eksponuje komercyjny charakter tej działalności. Według M. Geryka (2007) usługa edukacyjna to działalność, w której sprzedawca sprzedaje swoją wiedzę czy umiejętności, a nabywca je zdobywa. Natomiast R. Kolman (2003) uważa, że usługa edukacyjna to praca, której rezultatem jest nabycie wiedzy i kompetencji przez odbiorcę tej usługi. Wynika ona z roli zaspokajania potrzeby, jaką stanowi deficyt kompetencji niezbędnych do funkcjonowania w społeczeństwie. Z kolei G. Zieliński i K. Lewandowski (2012) wskazują, iż istotą usług edukacyjnych jest transfer kompetencji, w którym istotny element odgrywa wątek komercyjny. W tym transferze bierze udział sponsor usługi - na ogół państwo lub inna grupa podmiotów, świadczący usługę - wykwalifikowana osoba (nauczyciel, instruktor itp.) oraz odbiorca - uczący się (uczeń, student lub osoba dorosła).

Edukacją i usługami edukacyjnymi oraz ich efektywnością są zainteresowane różne grupy: uczniowie i rodzice, władze lokalne i centralne oraz pracodawcy. $Z$ tego też względu badania nad rozwojem edukacji i usługami edukacyjnymi powinny być prowadzone w różnych kontekstach. 


\section{ModernizaCJa STRUKTURY SZKOLNICTWA ŚREDNIEGO W PolsCe} W LATACH 1990-2012

W ostatnich 25 latach zaszły w polskim szkolnictwie istotne zmiany, wynikające z przeobrażeń ustrojowych i społeczno-gospodarczych, które wywarły duży wpływ na modernizację systemu szkolnego oraz programy kształcenia. Podstawą przeprowadzanych zmian w szkolnictwie podstawowym i średnim była ustawa z dnia 7 września 1991 r. o systemie oświaty. Wprowadziła ona m.in.: decentralizację systemu szkolnictwa, powierzenie realizacji zadań edukacyjnych samorządom, zmianę zasad finansowania oświaty, umożliwienie prowadzenia szkół przez różne podmioty. Przykładowo, w roku szkolnym 1990/1991 funkcjonowało 85 szkół niepublicznych, a w roku 1998/1999 było ich już 381 (czterokrotny wzrost). Niemniej jednak nadal większość szkół w Polsce, podobnie jak w wielu krajach UE, jest prowadzona przez państwo, a szkoły niepubliczne stanowią niewielki procent ogółu szkół (tab.1). Wyjątkiem jest Belgia, w której przeważają szkoły niepubliczne, zarówno we flamandzkiej, jak i we frankońskiej części (tab.1).

Tab. 1. Uczniowie w szkołach według organu prowadzącego w wybranych krajach UE (w \%)

\begin{tabular}{|l|r|c|c|c|c|c|}
\hline \multicolumn{1}{|c|}{ Szkoły } & UE & Czechy & Polska & Niemcy & Francja & Belgia \\
\hline publiczne & 82,0 & 93,7 & 93,6 & 92,6 & 78,5 & 32,3 \\
\hline prywatne z subwencją państwa & 10,1 & 6,3 & 1,0 & - & 20,5 & 67,7 \\
\hline prywatne bez subwencji państwa & 2,9 & - & 5,4 & - & 1,0 & - \\
\hline prywatne ogółem & 18,0 & 6,3 & 6,4 & 7,4 & 21,5 & 67,7 \\
\hline
\end{tabular}

Źródło: Kluczowe dane o edukacji w Europie (2012)

Podpisanie przez Polskę na początku lat dziewięćdziesiątych traktatu akcesyjnego o przystąpieniu do UE spowodowało konieczność dostosowania istniejących struktur szkolnictwa do rozwiązań funkcjonujących w większości krajów członkowskich. Reforma szkolnictwa z 1999 roku wydłużyła okres obowiązkowego kształcenia ogólnego młodzieży $\mathrm{z}$ ośmiu do dziewięciu lat, nawiązując tym samym do tendencji występujących w krajach zachodnioeuropejskich. Obowiązkowym kształceniem objęto uczniów szkół podstawowych (sześcioletnich) i gimnazjów (trzyletnich). W odniesieniu do szkolnictwa średniego (ponadgimnazjalnego) zmiany wdrożone od 2002 roku polegały na wprowadzeniu: trzyletnich liceów ogólnokształcących, czteroletnich techników, trzyletnich liceów profilowanych. Natomiast nie została zmieniona struktura zasadniczych szkół zawodowych (dwu- i trzyletnich) oraz szkół artystycznych dających uprawnienia zawodowe. Od roku szkolnego 2004/2005 do istniejącej struktury dołączono: dwuletnie uzupełniające licea ogólnokształcące i trzyletnie technika uzupełniające (na podbudowie programowej zasadniczej szkoły zawodowej) oraz trzyletnie szkoły specjalne przysposabiające do pracy (Tracz, 2001; Oświata i wychowanie, 2014; Ustawa o systemie oświaty).

Kolejna zmiana w systemie szkolnictwa nastąpiła w 2009 roku. Obniżono wiek obowiązku szkolnego z siedmiu do sześciu lat, dokonano też modernizacji programów kształcenia 
oraz systemu szkolnictwa ponadgimnazjalnego. Istotna reorientacja nastąpiła w szkolnictwie zawodowym, ponieważ wprowadzono nową klasyfikację zawodów. Zdefiniowano 200 zawodów powiązanych z 251 kwalifikacjami, a każda kwalifikacja została połączona z określonym zakresem wiedzy i umiejętności, aby jak najlepiej dostosować kwalifikacje zawodowe absolwentów do potrzeb rynku pracy. Opracowano także podstawę programową kształcenia w zawodach, uwzględniwszy założenia zawarte w Krajowych Ramach Kwalifikacji, opisującą efekty kształcenia dla wszystkich zawodów ujętych w przyjętej klasyfikacji. Wygaszona została rekrutacja do liceów profilowanych (od 2011 roku), zlikwidowano licea i technika uzupełniające, a pozostawiono szkoły przysposabiające do pracy (trzyletnie). U podstaw wdrażanych zmian w szkolnictwie zawodowym leży założenie, że bardziej elastyczne podejście do kształcenia zawodowego będzie sprzyjać szybszemu reagowaniu na potrzeby rynku pracy (Badanie funkcjonowania..., 2011a; Badanie funkcjonowania..., 2011b).

Dokonane zmiany systemu szkolnictwa oraz jego struktury w znacznym stopniu przyczyniły się do wzrostu współczynnika scholaryzacji brutto w grupie wiekowej 16-18 lat, z 39,4\% w 2000 roku do 53,7\% w 2010 roku. Odbywało się to kosztem malejącej liczby uczniów w zasadniczych szkołach zawodowych i technikach. W latach 1990/1991-2009/2010 najwyższe wartości wskaźnika scholaryzacji netto odnotowano dla liceów ogólnokształcących $(52,5 \%)$, techników i liceów profilowanych (29,6\%), a najniższe dla zasadniczych szkół zawodowych $(10,9 \%)$. Fakt ten miał bezpośrednie przełożenie na dalsze plany edukacyjne młodzieży. Nastąpił gwałtowny wzrost liczby studentów z 403 tys. w roku 1990/1991 do 1,584 mln w roku 2000/2001, zaś w roku 2005/2006 było już 1,953 mln studentów (Borowiec, 2011; Geryk, 2007; Tracz, 2001; Tracz, 2013).

Opinie środowiska nauczycielskiego o wprowadzonych zmianach strukturalnych szkolnictwa są niejednoznaczne. Wielu pedagogów, a także rodziców kwestionuje zasadność wprowadzonych rozwiązań, sugerując potrzebę przywrócenia jednolitego, ośmioklasowego kształcenia podstawowego i czteroletnich liceów ogólnokształcących. Jest to wynik m.in. trudności wychowawczych, z którymi spotykają się nauczyciele w gimnazjach. Na istniejące problemy w realizacji zadań wychowawczych i dydaktycznych przez współczesną szkołę wskazują także raporty Instytutu Badań Edukacyjnych i innych badaczy (Raport o stanie edukacji, 2011; Raport o stanie edukacji, 2012; Tracz, Świętek, 2015). Również wdrożone wczesne profilowanie kształcenia w szkołach ponadgimnazjalnych, szczególnie w liceach ogólnokształcących, jest przez część środowiska krytykowane. Wskazuje się przede wszystkim na dużą zmienność zainteresowań uczniów w tym wieku, a także na braki w zakresie wykształcenia ogólnego, jakie mogą powstać w wyniku realizacji owych programów (Raport o stanie edukacji, 2012; Tracz, 2013).

Do zalet dokonanej zmiany systemu oświatowego w Polsce po 1989 roku z punktu widzenia realizacji celów strategii uczenia się przez całe życie należy zaliczyć: wydłużenie obowiązku szkolnego, znaczne ograniczenie przedwczesnego kończenia edukacji przez młodzież (w wieku 16 lat) oraz autonomię szkół w zakresie procesu kształcenia, w tym programów kształcenia i organizacji. Natomiast finansowanie szkolnictwa nadal jest niezadowalające. Samorządy otrzymują na realizację coraz większych zadań edukacyjnych niewystarczające środki. Jest to jeden z istotnych czynników, przy malejącej liczbie uczniów, powodujących likwidację placówek oświatowych w małych miastach i wsiach (Tracz, 2013). 
ZRÓŻNICOWANIE ZAINTERESOWANIA MŁODZIEŻY TYPAMI SZKÓŁ PONADGIMNAZJALNYCH

W pierwszej omawianej dekadzie (1989-1999) zmiany struktury szkolnictwa nie odbywały się na skutek celowej polityki państwa, ale przede wszystkim zostały wymuszone przez gwałtownie zmieniającą się sytuację społeczno-gospodarczą oraz rynek pracy. Podjęty proces restrukturyzacji gospodarki, w tym przemysłu, przyczynił się do znacznej redukcji zatrudnienia, co spowodowało wzrost bezrobocia wśród osób z wykształceniem podstawowym i średnim zawodowym. Efektem tego procesu było zmniejszające się zainteresowanie młodzieży szkolnictwem zawodowym, co doprowadziło do likwidacji zasadniczych szkół przyzakładowych oraz spadku liczby szkół zawodowych (ryc. 1, ryc. 2). Równocześnie ujawniły się słabości systemu edukacyjnego, właściwe dla dawnego systemu polityczno-gospodarczego (realnego socjalizmu), czyli nadmiar pracowników z średnim wykształceniem technicznym, w specjalnościach związanych z przemysłem wydobywczym oraz maszynowym, przy jednoczesnym braku wykwalifikowanej kadry średniej z potrzebnych nowych branż - administracji, ekonomii, finansów i informatyki. Uczniowie w tej sytuacji częściej wybierali szkoły o profilu ogólnokształcącym. Wychodząc naprzeciw temu zainteresowaniu, w szkołach ogólnokształcących przygotowywano ofertę programów odpowiadających na potrzeby młodzieży, czyli zwiększono liczbę godzin z języków obcych i informatyki, uruchamiano nowe profile kształcenia (Tracz, 2001; Tracz, Mróz, 2003; Tracz, 2011).

W omawianej dekadzie (1989-1999) struktura szkolnictwa średniego nie uległa istotnym zmianom, natomiast zarysowały się ważne tendencje w wyborze przez młodzież typów szkół średnich (ryc. 1, ryc. 2). Odbyło się to kosztem głównie zasadniczych szkół zawodowych i techników. W kolejnej dekadzie (2000-2010) istotnie zmniejszył się nabór do szkół średnich zawodowych i techników, a zwiększył do liceów ogólnokształcących.

Natomiast w Unii Europejskiej jako całej strukturze obserwujemy w tym okresie tendencje do równoważenia liczby uczniów w szkołach średnich zawodowych i ogólnokształcących. Polska na tle UE i najbliższych sąsiadów wyróżnia się przewagą uczniów w szkołach o charakterze ogólnokształcącym (tab. 2, tab. 3). Można postawić tezę, że w Czechach, na Słowacji, a także w Niemczech szkoły ogólnokształcące nadal zachowały swój elitarny charakter placówek przygotowujących młodzież do podjęcia studiów uniwersyteckich. W Polsce, ze względu na masowy nabór do tego typu szkół, nastąpił znaczny spadek jakości kształcenia. Wynikł on po części z wyżu demograficznego i tym samym licznych klas, finansowania szkolnictwa zależnego od liczby uczniów oraz dewaluacji wykształcenia związanej z pogarszającą się sytuacją na rynku pracy. Oczywiście prowadzona polityka edukacyjna państwa, która premiowała szkolnictwo ogólnokształcące kosztem zawodowego, miała tutaj istotne znaczenie. Niektórzy badacze podkreślają, że duże aspiracje edukacyjne polskiej młodzieży, realizowane w szkołach umożliwiających uzyskanie matury, a następnie na studiach wyższych, chroniły ją przed bezrobociem (Denek, 2004). 
Ryc. 1. Zmiana struktury szkolnictwa ponadgimnazjalnego w Polsce w latach 1990-2012
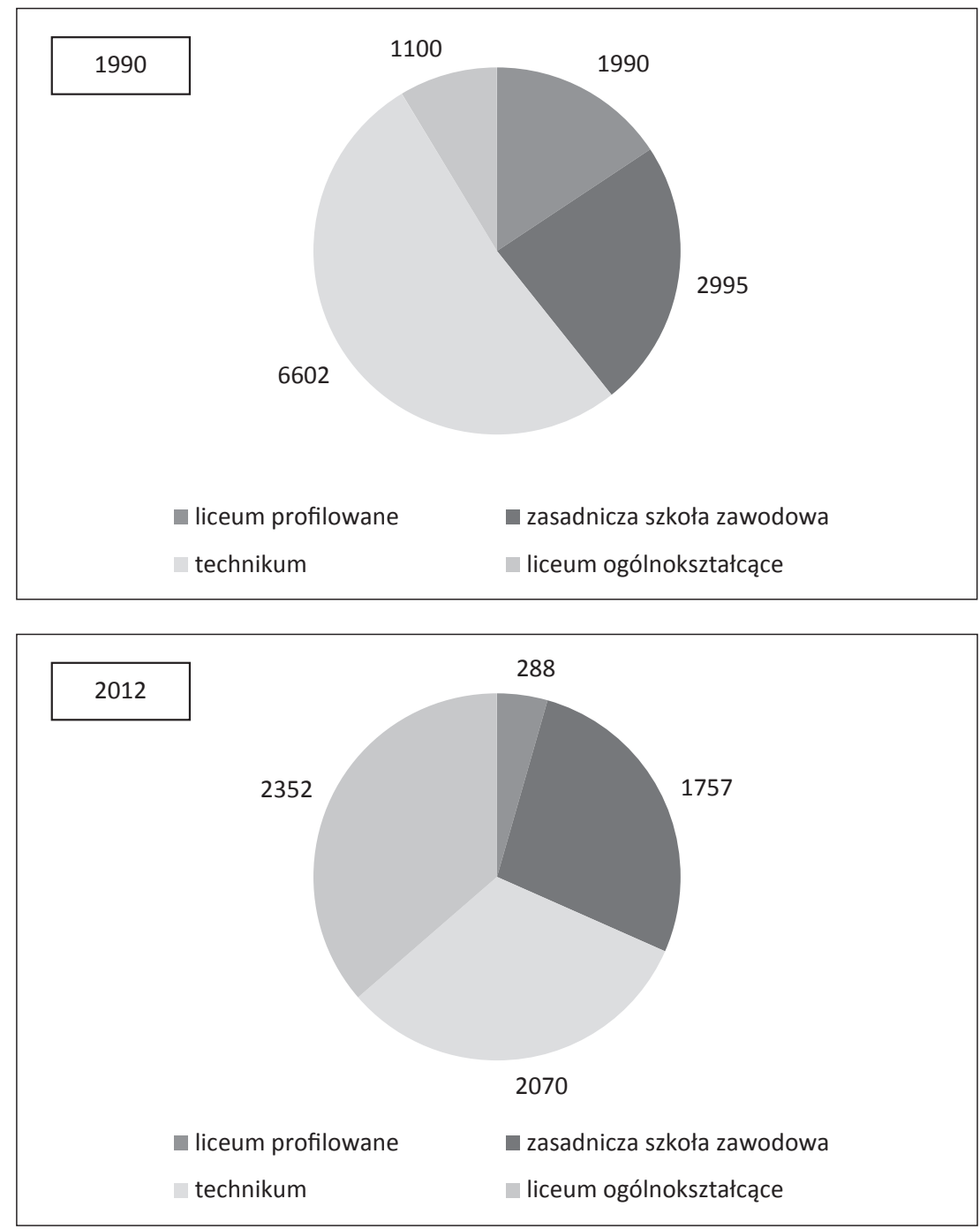

Źródło: opracowanie na podstawie Oświata i wychowanie... (2010, 2014) i Rocznik statystyczny (2013)

Licea profilowane, które umożliwiały uzyskanie wykształcenia ogólnego i równoległe zdobycie wykształcenia zawodowego, spotkały się ze znacznym zainteresowaniem młodzieży. W 2005 roku w tego typu szkołach kształciło się 201 tys. osób. W praktyce ten rodzaj szkoły okazał się dość trudny. Dla wielu uczniów przygotowanie się do egzaminu maturalnego oraz uzyskanie uprawnień zawodowych w ciągu trzech lat było dużym wyzwaniem. Równocześnie rynek pracy był bardziej zainteresowany absolwentami techników niż liceów profilowanych. $Z$ tego też powodu systematycznie zmniejszał się nabór uczniów do tego typu szkół w kolejnych latach (ryc. 2). W 2011 roku Ministerstwo Edukacji Narodowej podjęło decyzję o wygaszaniu naboru do liceów profilowanych. 
Ryc. 2. Liczba uczniów w różnych typach szkół ponadgimnazjalnych w Polsce w latach 1990-2012 (w tys.)

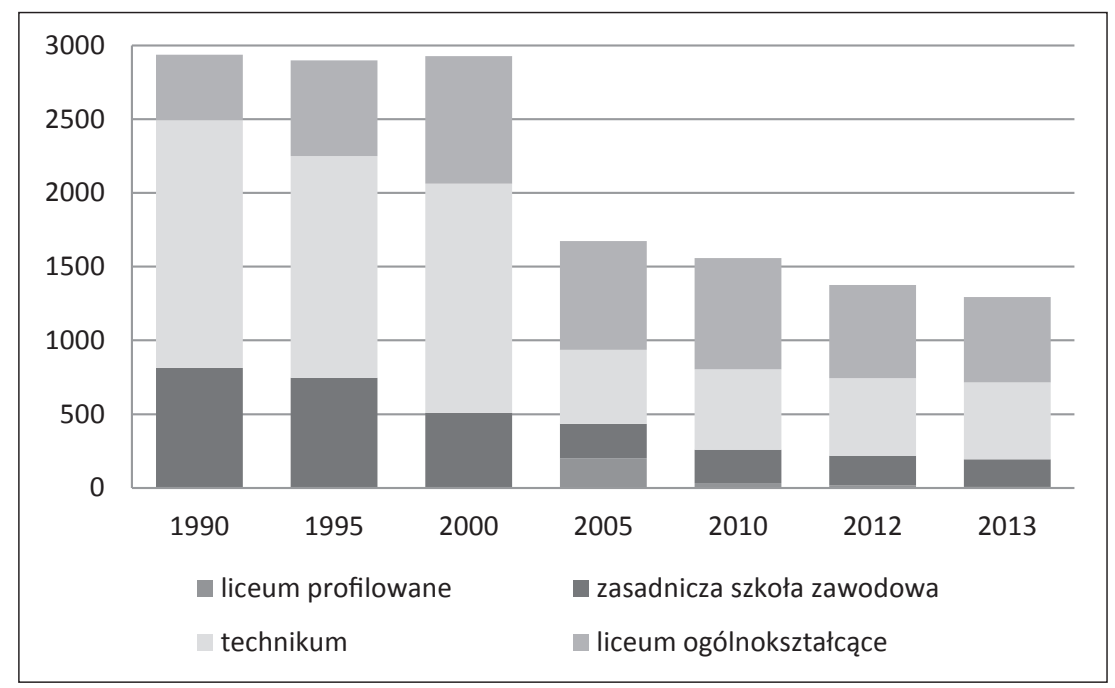

Źródło: Oświata i wychowanie... (2010, 2014) i Rocznik statystyczny (2013)

Tab. 2. Uczniowie w szkołach średnich zawodowych w wybranych krajach UE (w \%)

\begin{tabular}{|l|c|c|c|c|c|}
\hline \multicolumn{1}{|c|}{ Wyszczególnienie } & UE & Niemcy & Czechy & Polska & Słowacja \\
\hline mężczyźni & 55,2 & 60,5 & 78,8 & 57,1 & 76,8 \\
\hline kobiety & 43,2 & 44,5 & 67,8 & 36,1 & 66,4 \\
\hline ogółem & 49,6 & 57,3 & 73,3 & 47,2 & 71,9 \\
\hline
\end{tabular}

Źródło: Kluczowe dane o edukacji w Europie (2012)

Tab. 3. Uczniowie w szkołach ogólnokształcących w wybranych krajach UE (w \%)

\begin{tabular}{|l|c|c|c|c|c|}
\hline \multicolumn{1}{|c|}{ Wyszczególnienie } & UE & Niemcy & Czechy & Polska & Słowacja \\
\hline mężczyźni & 44,8 & 34,5 & 21,3 & 42,9 & 23,2 \\
\hline kobiety & 58,2 & 55,5 & 32,2 & 63,9 & 33,6 \\
\hline ogółem & 50,4 & 46,6 & 26,7 & 52,82 & 28,4 \\
\hline
\end{tabular}

Źródło: Kluczowe dane o edukacji w Europie (2012)

W analizowanym okresie zmniejszyła się liczba uczniów uczęszczających do poszczególnych typów szkół ponadgimnazjalnych. W latach 1990-2000 liczba młodzieży w szkołach średnich utrzymywała się na zbliżonym poziomie. Od 2005 roku uwidaczniał się spadek liczby uczniów we wszystkich typach szkół ponadgimnazjalnych, przy czym był on najłagodniejszy w liceach ogólnokształcących (ryc. 2). Spowodowane było to zachodzącymi procesami demograficznymi - mniej osób w grupie wiekowej 0-6 i 7-18 lat, a także wygaszaniem naboru do liceów profilowanych, liceów i techników uzupełniających. Według prognoz demograficznych niekorzystna sytuacja w grupie wiekowej 15-19 lat będzie się utrzymywać do 2020 roku. 
Płeć jest ważnym czynnikiem wpływającym na wybór danego typu szkoły ponadgimnazjalnej. Występuje wyraźna tendencja do preferowania przez kobiety (uczennice) szkół o profilu ogólnokształcącym. W liceach ogólnokształcących liczba kobiet przewyższa liczbę mężczyzn (uczniów). Z danych GUS wynika, iż od 1995 roku występuje jednak stała tendencja do wyrównywania struktury płci w liceach ogólnokształcących. Z kolei szkoły o profilu zawodowym - technika i zasadnicze szkoły zawodowe - są znacznie częściej wybierane przez mężczyzn niż przez kobiety (ryc. 3).

Ryc. 3. Struktura młodzieży wg płci w szkołach ponadgimnazjalnych w Polsce w roku szkolnym $2005 / 2006$ i 2012/2013
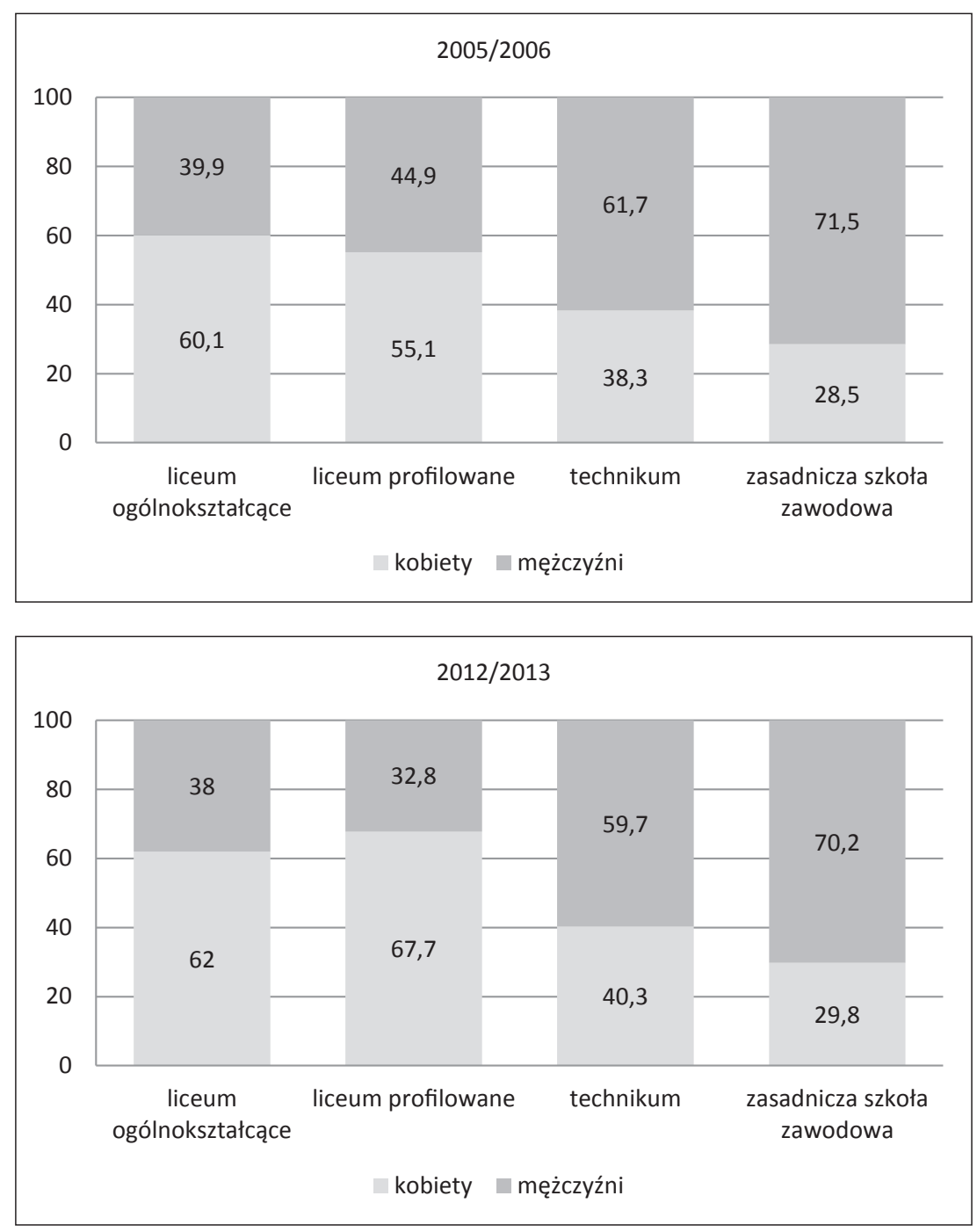

Źródło: Rocznik statystyczny RP (2013) 
Analiza liczby uczniów w poszczególnych typach szkół ponadgimnazjalnych wg województw wykazała występowanie różnic regionalnych. Od lat uczniowie w wieku 16-18 lat częściej wybierają licea ogólnokształcące (ryc. 2). W roku szkolnym 2012/2013 kształciło się w tego typu szkołach 44,4\% uczniów. Najwyższy współczynnik scholaryzacji netto w liceach ogólnokształcących odnotowano w województwach mazowieckim $(53,2 \%)$ i lubelskim (51,9\%), a najniższy w województwach: opolskim $(36,5 \%)$, lubuskim $(37,2 \%)$ i kujawsko-pomorskim (37,7\%). Z kolei kształcenie w technikach częściej wybierali uczniowie w województwach: świętokrzyskim (38\%), podkarpackim (37\%), pomorskim (38\%) i śląskim (37\%). Natomiast w analizowanym roku szkolnym do zasadniczych szkół zawodowych uczęszczało 13,2\% uczniów w wieku 16-18 lat. Największe zainteresowanie tego typu szkołami wykazali uczniowie z województw: wielkopolskiego $(18,1 \%)$, kujawsko-pomorskiego (16,6\%) i opolskiego (16,5\%) (Oświata i wychowanie..., 2014). Wyjaśnienie istniejących różnic w preferencjach wyboru przez młodzież typów szkół w poszczególnych regionach wymaga podjęcia bardziej szczegółowych badań.

Rekapitulując, można stwierdzić, że na zmianę struktury kształcenia na poziomie średnim w Polsce oraz wzrost liczby uczniów w liceach ogólnokształcących istotny wpływ miały:

- zmiany na rynku pracy (spadek popytu na pracowników na stanowiskach robotniczych i średniego personelu technicznego, wynikające m.in. z ograniczenia produkcji przemysłowej, zmian w zarządzaniu, rozwoju instytucji finansowych - banków, giełdy),

- większe aspiracje edukacyjne i zawodowe młodzieży wynikające z poprawy relacji między poziomem dochodów a wykształceniem,

- realizacja założeń polityki edukacyjnej wyznaczonej przez UE w ramach strategii lizbońskiej oraz strategii kwalifikacji zawodowej (Raport o stanie edukacji, 2011; Raport o stanie edukacji, 2012; Tracz, Mróz, 2003; Tracz, Borowiec, Mróz, 2009),

- niekorzystne zmiany demograficzne występujące w Polsce po 1989 roku,

- indywidualne preferencje edukacyjne młodzieży.

\section{ZRÓŻNICOWANIE KIERUNKÓW KSZTAŁCENIA W SZKOŁACH PONADGIMNAZJALNYCH}

Rosnąca liczba uczniów w liceach ogólnokształcących powodowała uruchamianie najróżniejszych profili kształcenia. Szkoły konkurowały ze sobą, oferując coraz to nowsze profile (prawny, lingwistyczny, europejsko-językowy, informatyczno-matematyczny itp.). Jednak wśród uczniów nadal większym zainteresowaniem cieszą się profile humanistyczne i przyrodnicze niż ścisłe (matematyka, fizyka). W liceach ogólnokształcących cieszących się uznaną renomą społeczną, tzw. dobrych, obserwuje się większe zrównoważenie dokonywanego przez uczniów wyboru profilu kształcenia. W szkołach tych często funkcjonuje kilka oddziałów klasowych o podobnym lub zbliżonym profilu.

W szkołach ponadgimnazjalnych zawodowych możemy mówić o zmianie preferencji kształcenia. W pierwszym okresie transformacji ujawnia się wyraźne odchodzenie od kształcenia w zawodach robotniczych i średniego personelu technicznego, związanych z przemysłem ciężkim i maszynowym. Po tym okresie, w wyniku wprowadzonej reformy szkolnictwa oraz zapotrzebowania rynku pracy, następuje przebudowa profili kształcenia. Uwidacznia 
się wzrost zainteresowania profilami związanymi z usługami dla ludności (personel obsługi klienta), profilami nauk technicznych (informatyka, budownictwo i architektura, ochrona środowiska) i administracyjnych (ekonomia, administracja, biznes), a także takimi zawodami, jak: technik elektryk, technik elektronik oraz sprzedawca (Tracz, 2001; Tracz, Borowiec, Mróz, 2009; Badanie funkcjonowania ..., 2011a; Zaborek, 2011; Jelonek, Szklarczyk, 2012).

W ostatniej dekadzie omawianego okresu nie widać wyraźnych różnic wśród najpopularniejszych kierunków kształcenia zawodowego. W technikach najczęściej wybierane zawody to: technik informatyk, technik ekonomista i technik hotelarstwa. Natomiast niewielkim zainteresowaniem cieszą się zawody technik rolnik i technik elektryk (tab. 4). Badania P. Zaborka (2011) nad zróżnicowaniem profili kształcenia w szkolnictwie ponadgimnazjalnym w miastach powyżej 100 tys. mieszkańców uwidoczniły wpływ wielkości ośrodka na popularność kierunków kształcenia. W dużych ośrodkach miejskich uczniowie częściej wybierają profile związane z usługami osobistymi (np. technik usług kosmetycznych, technik usług fryzjerskich), a także takie zawody, jak technik organizacji reklamy czy technik logistyk. W liceach profilowanych, do których nabór jest wygaszany, do najczęściej wybieranych profili kształcenia należały: zarządzanie informacją, administracyjno-ekonomiczny i socjalny. Kobiety wybierają najczęściej kształcenie związane z usługami dla ludności, ekonomią i administracją oraz społeczne. Natomiast mężczyźni wybierają profile związane z kształceniem informatycznym i technicznym (Oświata i wychowanie..., 2010; Oświata i wychowanie..., 2013).

W zasadniczych szkołach zawodowych do najczęściej wybieranych kierunków kształcenia należą te powiązane z usługami dla ludności: mechanik pojazdów samochodowych, kucharz małej gastronomii, fryzjer i sprzedawca (tab. 4). Blisko 1/4 uczniów tego typu szkół wybiera zawody związane z serwisem pojazdów samochodowych (mechanik, elektromechanik, blacharz, lakiernik). Jest to m.in. efekt likwidacji zakładów przemysłowych, zwłaszcza w małych ośrodkach miejskich. Aktualnie uczniowie wybierają na ogół te kierunki kształcenia, które stwarzają możliwości samozatrudnienia, np. w sferze usług powiązanych z dynamicznie rozwijającą się motoryzacją. Podobnie jak w przypadku techników, kobiety wybierają głównie zawody związane z usługami dla ludności, a mężczyźni z grupy technicznych, budowniczych i rolniczych.

Tab. 4. Najpopularniejsze kierunki kształcenia w technikach, liceach profilowanych i zasadniczych szkołach zawodowych w 2011 roku

\begin{tabular}{|l|l|l|}
\hline \multicolumn{1}{|c|}{ Technika } & \multicolumn{1}{c|}{ Licea profilowane } & \multicolumn{1}{c|}{$\begin{array}{c}\text { Zasadnicze szkoły } \\
\text { zawodowe }\end{array}$} \\
\hline technik informatyk & zarządzanie informacją & $\begin{array}{l}\text { mechanik pojazdów } \\
\text { samochodowych }\end{array}$ \\
\hline technik ekonomista & ekonomiczno-administracyjne & kucharz małej gastronomii \\
\hline technik hotelarstwa & administracyjne & fryzjer \\
\hline muzyk & socjalne & sprzedawca \\
\hline $\begin{array}{l}\text { technik pojazdów } \\
\text { samochodowych }\end{array}$ & usługi osobiste & murarz \\
\hline technik administracji & usługowo-gospodarcze & cukiernik \\
\hline
\end{tabular}




\begin{tabular}{|l|l|l|}
\hline technik budowlany & transportowo-spedycyjne & ślusarz \\
\hline technik elektronik & kreowanie ubiorów & $\begin{array}{l}\text { elektromechanik pojazdów } \\
\text { samochodowych }\end{array}$ \\
\hline technik fryzjer & kształtowanie środowiska & piekarz \\
\hline technik logistyk & ochrona środowiska & blacharz samochodowy \\
\hline
\end{tabular}

Źródło: opracowano na podstawie: System informacji oświatowej; Zaborek (2011); Jelonek, Szklarczyk (2012)

Podsumowując informacje na temat preferencji młodzieży związanych z kierunkami kształcenia ponadgimnazjalnego, należy zwrócić uwagę na:

- preferowanie przez młodzież szkół dających możliwość uzyskania świadectwa maturalnego,

- zwiększony udział w kształceniu zawodowym zawodów z grupy: informatycznej, średniego personelu do spraw biznesu i administracji oraz usług dla ludności,

- zwiększone zainteresowanie uczniów zasadniczych szkół zawodowych zawodami z grupy usług dla ludności,

- stale zmniejszające się zainteresowanie młodzieży kształceniem związanym z przemysłem i rolnictwem.

\section{Podsumowanie}

Większość wskazanych trendów w rozwoju usług szkolnictwa ponadgimnazjalnego w Polsce w latach 1989-2012 była wymuszona zmianami gospodarczymi zachodzącymi w skali globalnej i lokalnej. Dodatkowo nałożyły się na to niekorzystne zmiany demograficzne. Uwidoczniły się także dość luźne powiązania między długookresową polityką rozwoju gospodarczego a polityką edukacyjną państwa. Miało to negatywne konsekwencje, prowadzące do znacznego wzrostu bezrobocia wśród młodych ludzi, absolwentów szkół średnich zawodowych.

Współcześnie planowanie ścieżki edukacyjnej i kariery zawodowej jest znacznie utrudnione ze względu na ukierunkowanie rozwoju gospodarczego opartego na dominacji sektora usług, a wyraźne zaniedbanie działalności przemysłowej. Dlatego też młodzi ludzie, analizując możliwości rozwoju zawodowego, wybierają często dalsze kształcenie na uczelni lub w zawodach, które dają perspektywę zatrudnienia w małej firmie bądź prowadzenie własnej działalności, niewymagającej dużych nakładów finansowych. Dlatego najmniej popularne są kierunki kształcenia związane z przemysłem surowcowym, maszynowym oraz rzemieślnicze i robotnicze.

Do pozytywnych zmian, wynikających z dokonanych przemian strukturalnych szkolnictwa średniego i wdrożonych reform programowych, należy zaliczyć wzrost współczynnika scholaryzacji brutto i netto w grupie wiekowej 16-18 lat. Ta część młodzieży coraz dłużej się uczy, a tym samym poziom wykształcenia średniego ludności znacznie się zwiększył. Powstaje pytanie: na ile w dłuższym okresie dokonane zmiany systemu oświatowego 
i oferowanych kierunków kształcenia, zwłaszcza w szkolnictwie zawodowym, będą w stanie efektywnie przeciwdziałać negatywnym procesom zachodzącym na rynku pracy?

Niepokoi może zawężanie edukacji tylko do patrzenia na nią jako na usługę o charakterze komercyjnym, mającą sprostać wymaganiom rynku pracy. Cele procesu uczenia się nie mogą ograniczać się tylko do nabycia utylitarnej wiedzy i umiejętności związanych z profilem kształcenia oraz zdolności do zatrudnienia, czyli zestawu pewnych umiejętności związanych z odniesieniem sukcesu w zawodzie. Takie rozumienie roli edukacji w procesie rozwoju cywilizacji powoduje jej odhumanizowanie, oderwanie od systemu wartości, pragnień i potrzeb duchowych człowieka. Możliwości adaptacyjne człowieka do szybko zachodzących zmian kulturowych i technologicznych wymagają bardziej holistycznego podejścia do kształcenia.

\section{Literatura \\ References}

Badanie funkcjonowania systemu kształcenia zawodowego w Polsce. Raport końcowy (2011a). Warszawa: Ministerstwo Edukacji Narodowej.

Badanie funkcjonowania systemu ksztatcenia zawodowego w Polsce. Raport z badania danych wtórnych - desk research (2011b). Warszawa: Ministerstwo Edukacji Narodowej.

Borowiec, M. (2010). Rola edukacji w procesach globalizacji. Przedsiębiorczość-Edukacja, 7, 13-20.

Borowiec, M. (2011). Zmiany kierunków kształcenia akademickiego w Polsce. Prace Komisji Geografii Przemystu Polskiego Towarzystwa Geograficznego, 18, 9-22.

Denek, K. (2004). Uniwersytet w służbie społeczeństwa wiedzy. W: E. Kula, M. Pękowska (red.). Szkolnictwo wyższe $w$ Polsce $i$ w Europie $w$ świetle zatożeń i realizacji procesu bolońskiego. Kielce: Wszechnica Świętokrzyska.

Education at a Glance 2014 (2014). OECD.

Geryk, M. (2007). Rynek uczelni niepublicznych w Polsce. Warszawa: Wydawnictwo Szkoły Głównej Handlowej.

Godlewska-Majkowska, H. (2007). System edukacyjny wobec potrzeb rozwojowych schyłkowych regionów przemysłowych. W: J. Lach, M. Borowiec, T. Rachwał (red.). Procesy transformacji społeczno-ekonomicznych i przyrodniczych struktur przemysłowych. Kraków: Wydawnictwo Naukowe Akademii Pedagogicznej, 600-610.

Jelonek, M., Szklarczyk, M. (2012). Kogo ksztatca polskie szkoły. Analiza kierunków ksztatcenia w szkotach ponadgimnazjalnych $i$ wyższych. Warszawa: Polska Agencja Rozwoju Przedsiębiorczości.

Kluczowe dane o edukacji w Europie (2012). EURYDICE. Warszawa: Fundacja Rozwoju Systemów Edukacji.

Kotler, P. (2002). Marketing. Podręcznik europejski. Warszawa: Państwowe Wydawnictwa Ekonomiczne.

Kudełko, J. (2007). Rozwój społeczno-gospodarczy województwa podkarpackiego i poziom jego konkurencyjności na tle kraju. W: J. Lach, M. Borowiec, T. Rachwał (red.). Procesy transformacji społeczno-ekonomicznych i przyrodniczych struktur przemysłowych. Kraków: Wydawnictwo Naukowe Akademii Pedagogicznej, 473-489.

Kupisiewicz, C., Kupisiewicz, M. (2009). Słownik pedagogiczny. Warszawa: PWN.

Okoń, W. (2007). Stownik pedagogiczny. Warszawa: Wydawnictwo Akademickie Żak.

Oświata i wychowanie w roku szkolnym 2009/2010 (2010). Warszawa: GUS.

Oświata i wychowanie w roku szkolnym 2013/2014 (2014). Warszawa: GUS.

Raport o stanie edukacji. Kontynuacja przemian (2011). Warszawa: Instytut Badań Edukacyjnych.

Raport o stanie edukacji. Licza się efekty (2012). Warszawa: Instytut Badań Edukacyjnych. 
Rocznik statystyczny RP (2013). Warszawa: GUS.

Skrzypek, E. (2006). Jakość w oświacie, uwarunkowania i czynniki sukcesu. Problemy Jakości, 2, $16-17$.

Tkocz, M. (2007). Procesy transformacji województwa śląskiego w XXI wieku. W: J. Lach, M.

Borowiec, T. Rachwał (red.). Procesy transformacji spoleczno-ekonomicznych i przyrodniczych struktur przemystowych. Kraków: Wydawnictwo Naukowe Akademii Pedagogicznej.

Tracz, M. (2001). Edukacja. W: Encyklopedia geograficzna świata. Suplement. Kraków: OPRES.

Tracz, M. (2013). Kapitał społeczny w Polsce. Prace Komisji Geografii Przemystu Polskiego Towarzystwa Geograficznego, 23, 134-145.

Tracz, M. Borowiec, M., Mróz, G. (2009). Szkolnictwo w województwie podkarpackim. Folia Geographica. Series Geographica Oeconomica, 33, 103-118.

Tracz, M., Mróz, G. (2003). Szkolnictwo w województwie małopolskim. Folia Geographica. Series Geographica Oeconomica, 31-32, 207-223.

Tracz, M., Świętek, A. (2015). Zmiany programowe nauczania geografii w rzeczywistości szkolnej na przykładzie gimnazjum. Annales Universitatis Paedagogicae Cracoviensis, 162. Studia Geographica, 6, 53-66.

Ustawa o systemie oświaty. Dz.U z 2004 r. nr 256, poz. 2572 z późn. zm.

Zaborek P. (2011). Zróżnicowanie profili kształcenia w szkolnictwie ponadgimnazjalnym. Warszawa: Uniwersytet Warszawski.

Zieliński, G., Lewandowski, K. (2012). Determinanty percepcji jakości ustug edukacyjnych w perspektywie grup interesariuszy. Pozyskano z http://jm.f.wzr.pl/pim/2012_3_3_h.pdf

Mariola Tracz, doktor, geograf, członek Polskiego Towarzystwa Geograficznego. Zainteresowania naukowe: dydaktyka geografii (programy nauczania, edukacja geograficzna a rozwój kompetencji, kształcenie nauczycieli geografii i podstaw przedsiębiorczości, historia geografii i jej dydaktyki), geografia społeczno-gospodarcza (polityka edukacyjna państwa, system szkolny a gospodarka).

Mariola Tracz, Ph.D., geographer, member of the Polish Geographical Society. Interested in: geography education (curriculum development, education and development of geography competency, geography and enterprise teacher training, history of geography education), socio-economic geography (educational policy, system of education and economic development).

\section{Adres/ address:}

Polskie Towarzystwo Geograficzne

Oddział w Krakowie

ul. Podchorążych 2

30-084 Kraków, Polska

e-mail: mtracz-62@o2.pl; mtracz@up.krakow.pl 